\title{
How Red Tides Impact Manatees ${ }^{1}$
}

\author{
Brittany Hall-Scharf and Armando Ubeda²
}

\section{Introduction}

Persistent red tides can be one of the largest killers of one of the state's most iconic species, the Florida manatee, Trichechus manatus latirostris. Between September 2017 and October 2018, a more than year-long red tide bloom along parts of Florida's Gulf Coast killed almost 200 manatees. Additional red tide blooms were found along Florida's Panhandle and Atlantic Coast in September 2018.

Protecting manatees from the threat of red tide makes good sense for the state's coastal counties. In Citrus County, manatees generate a positive economic benefit, drawing large numbers of tourists wanting to get a glimpse of the gentle giants (Citrus County; Solomon et al. 2004).

Manatees also play an important role in maintaining a healthy coastal environment. The plant-eating mammals help maintain coastal and riverine systems by eating aquatic vegetation. When manatees feed on rooted aquatic plants, including seagrasses, their trimming of the grass blades stimulates new growth, which contributes to the overall health of the seagrass beds (NOAA 2011). Manatees also eat floating vegetation that might otherwise block canals.

Despite their contributions to Florida's culture and environment, manatee populations fell so low in the recent past that they were listed as endangered and given federal and state protections. The population has since rebounded enough that the US Fish and Wildlife Service reclassified manatees from endangered to threatened in 2017.
Computer simulations now predict the species has a low probability of extinction over the next 100 years.

However, if threats to manatee survival are not controlled moving forward, and the extinction risk increases, manatees may need to once again be classified as endangered. Understanding how red tides affect manatees, how red tide's persistence can be reduced, and how humans can help, is critical to protecting Florida's manatee population for generations to come.

This publication will explain what the term red tide means, why red tide is harmful manatees, and what you can do to help this iconic Florida species.

\section{What is red tide?}

Red tide is a conversational term used to describe a particular type of harmful algal bloom. Harmful algal blooms occur worldwide. In Florida, red tide is caused by an accumulation of the microscopic algae, Karenia brevis (Figure 1), a naturally occurring organism found throughout the Gulf of Mexico, occasionally on the east coast of Florida, and as far north as North Carolina. This organism can survive in both marine and brackish waters but cannot tolerate low-salinity, or fresh waters such as lakes and rivers.

Red tide can occur during every month of the year. However, in south Florida, red tide is more prominent during the fall, winter, and spring (Brand and Compton 2007). According to the Florida Fish and Wildlife Conservation

1. This document is SG188, one of a series of the Sea Grant Department, UF/IFAS Extension. Original publication date March 2019. Visit the EDIS website at for the currently supported version of this publication.

2. Brittany Hall-Scharf, Florida Sea Grant agent, UF/IFAS Extension Hernando County; and Armando Ubeda, Florida Sea Grant agent, UF/IFAS Extension Sarasota County; UF/IFAS Extension, Gainesville, FL 32611.

The Institute of Food and Agricultural Sciences (IFAS) is an Equal Opportunity Institution authorized to provide research, educational information and other services only to individuals and institutions that function with non-discrimination with respect to race, creed, color, religion, age, disability, sex, sexual orientation, marital status, national origin, political opinions or affiliations. For more information on obtaining other UF/IFAS Extension publications, contact your county's UF/IFAS Extension office. 
Commission (FWC), blooms typically originate 10-40 miles offshore and are transported inshore by winds and currents. When close to shore, the red tide algae can feed on nitrogen, phosphorus, and other nutrients introduced to the environment from human activities including fertilizer runoff from urban, suburban, and agricultural areas. Excess nutrients feed algal blooms, causing them to proliferate and linger in nearshore waters.

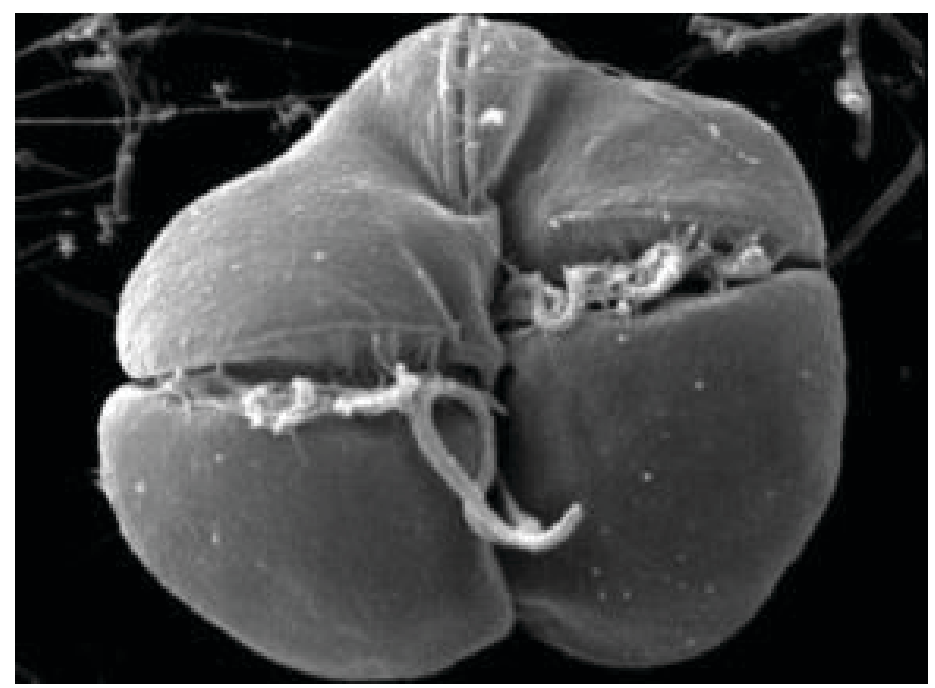

Figure 1. The organism that causes red tide in Florida is thousands of times smaller than objects seen using a conventional microscope. It requires magnification through electron microscopy.

Credits: Florida Fish and Wildlife Conservation Commission

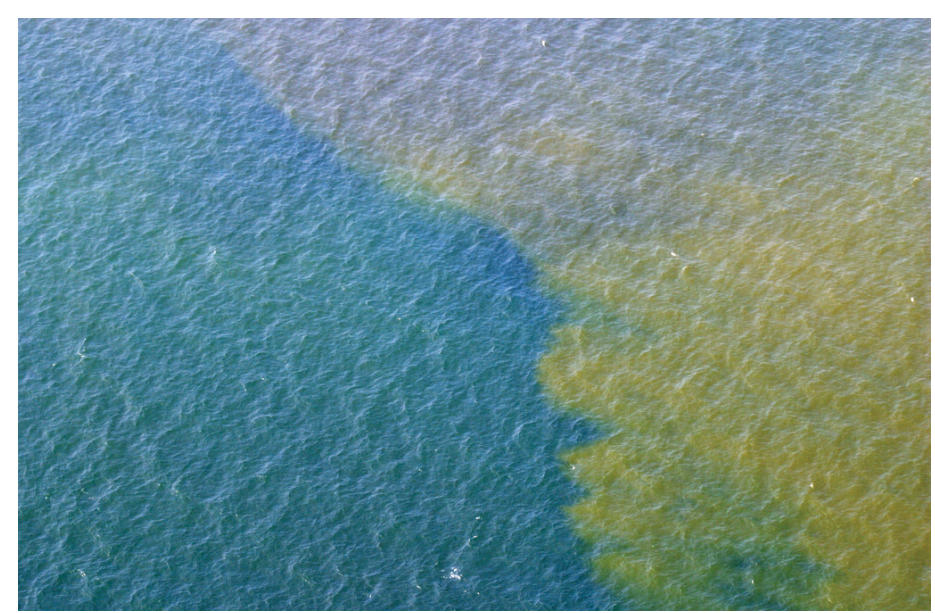

Figure 2. When the algae that causes red tide multiplies in sufficient numbers, it produces blooms with a visible reddish cast in ocean waters.

Credits: Florida Fish and Wildlife Conservation Commission

Blooms of Karenia brevis are considered harmful because they produce brevetoxins, a type of poison that affects the nervous system of fish and other vertebrates. The toxins are not only a problem in the water column. Red tide cells are fragile and rupture easily at the water's surface, sending neurotoxins into the air. When inhaled or ingested at high enough concentrations, these neurotoxins can kill not only fish, but birds and marine mammals like manatees.
Red tide blooms create health threats for people, too. They can have serious implications for those with chronic respiratory conditions as far as three miles inland. Swimming in an area with a red tide bloom can cause skin and eye irritation (Kirkpatrick et al. 2004). Eating scallops, clams, oysters, and other bivalves from waters experiencing a red tide bloom is unsafe, so recreational and commercial harvest of shellfish is closed when red tide is present in Florida.

\section{How does red tide harm manatees?}

Florida manatees are large, plant-eating marine mammals that migrate between fresh and salt water, primarily feeding on aquatic vegetation. In salt and brackish waters, their diet consists mostly of seagrasses. Epiphytes, such as small crustaceans and barnacles, grow on seagrass blades and feed by filtering out particles from the surrounding waters. During persistent red tide blooms, epiphytes remove large amounts of red tide cells from the water and concentrate the toxin-producing algae in their gut. These toxins, while not harmful to the epiphytes, can poison manatees when they consume the seagrass (Capper et al. 2002; Flewelling 2008; Landsberg et al. 2004).

Manatees can take in airborne red tide toxins as well. Because manatees are mammals, they must swim to the surface to breathe through their nostrils as often as every 30 seconds when active and expending energy. Even when they are sleeping, they must surface at least every 20 minutes. If manatees pass through a bloom, they can inhale airborne brevetoxins released from the red tide cells.

When manatees are poisoned by red tide, they suffer symptoms similar to a seizure and lose control of motor function. Ultimately, they die by drowning as they inadvertently inhale water during a convulsive episode. With timely intervention, manatees suffering from red tide toxins can be provided supportive care to prevent them from drowning.

\section{How are red-tide affected manatees rescued?}

Once a sick or injured manatee is reported to the FWC and aquarium wildlife hotlines, rescue teams must work quickly and efficiently to rescue it. These rescues can take a team of trained biologists and volunteers hours to complete. Often, the health of a sick or distressed manatee has been declining for days before the animal is located and 
reported, making every minute during the rescue crucial to the manatee's survival.

Because the location of a manatee can be unpredictable and a stranding can occur at any time, simply arriving on site can take the team hours. Teams must take time to load the proper equipment and sometimes need to travel long distances to reach the distressed animal. Thus, the FWC and aquariums often dispatch locally trained volunteers to assess the scene and monitor and/or assist the manatee while they wait for the rescue team to arrive.

Volunteer teams record the animal's vitals and other important data while waiting for the rescue team to arrive (Figure 3). This includes recording the manatee's rate of breathing and making other behavioral observations, taking samples of bodily discharge, and taking pictures. In order to help manatees stay afloat while they are paralyzed or having seizures, teams sometimes use floatation aids like pool noodles. (Please note that tampering with a manatee in the wild is a second-degree misdemeanor and only those who have been properly trained can assist with these rescues.)

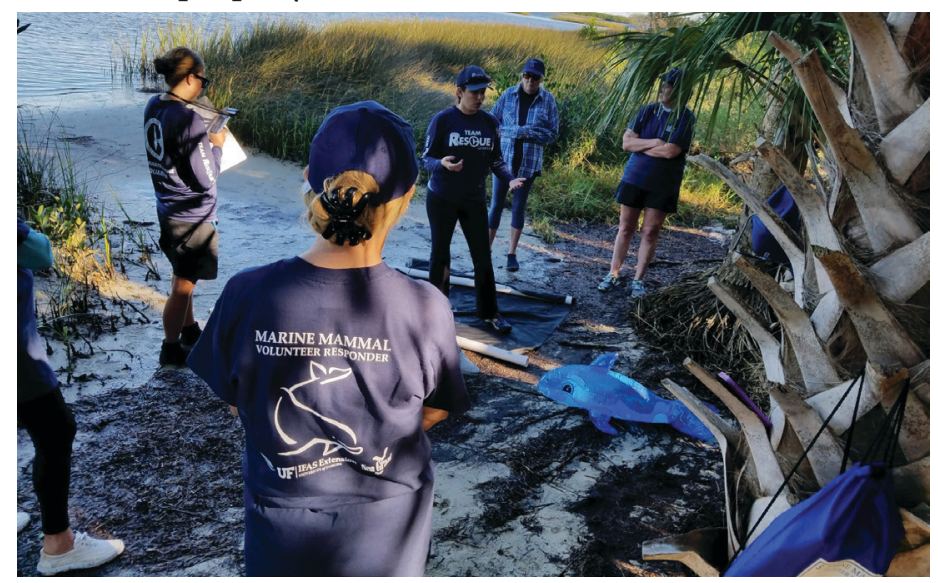

Figure 3. Local volunteers in Hernando County work with Clearwater Marine Aquarium biologists on marine mammal stranding response and rescue skills. Once certified, volunteers are called to assist and are often the first responders on site.

Credits: Brittany Hall-Scharf, UF/IFAS

Upon arrival to the rescue site, veterinary staff and biologists further assess the health of the manatee by continuing to monitor breathing rates and behavior and taking blood samples (Figure 4) and weight measurements (Figure 5).

The team then contacts the nearest critical care facility to see if they have space and resources to stabilize and treat the animal. There are four of these facilities in the United States, all in Florida. Veterinarians and aquarium staff at the Jacksonville Zoo and Gardens, SeaWorld Orlando, Miami Seaquarium, and the Lowry Park Zoo assess the incoming patients and create a treatment plan to prepare them for their release back into the wild.

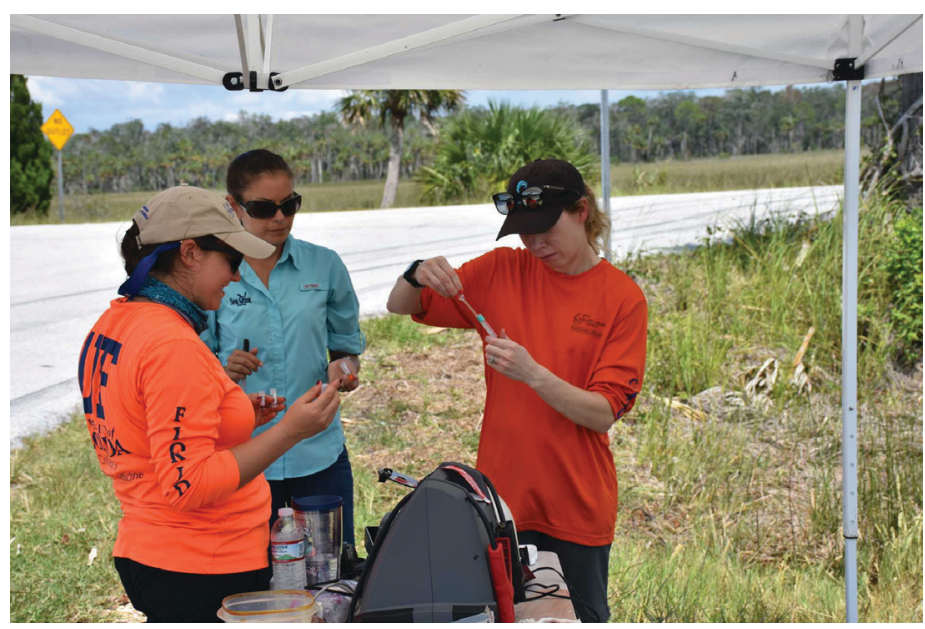

Figure 4. Blood samples are taken from sick and distressed manatees at rescue sites by biologists and veterinarians to determine the next steps of rehabilitation and release.

Credits: University of Florida Aquatic Animal Health

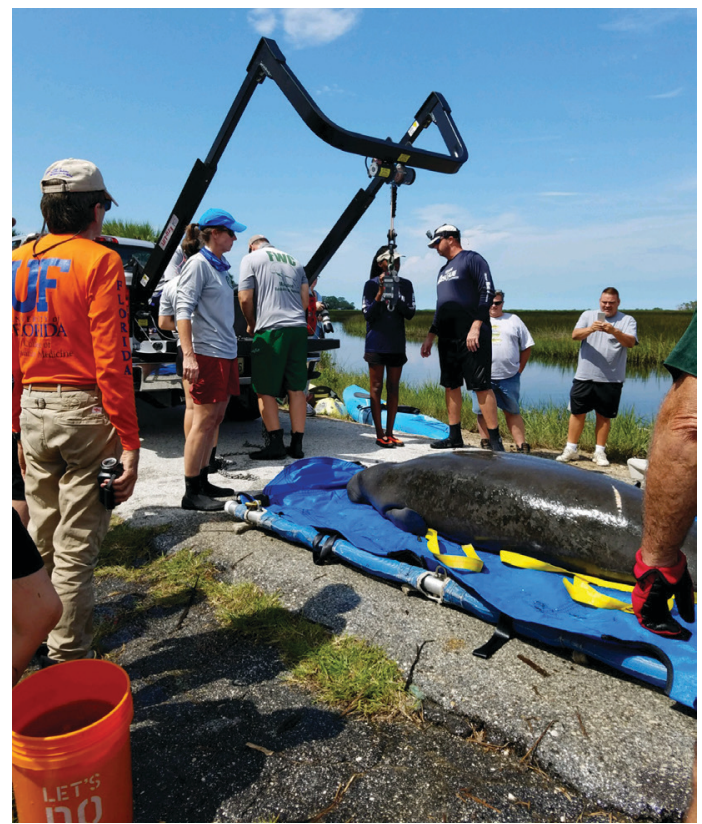

Figure 5. Rescue teams have specialized equipment that they can bring to stranding sites to better assess the health of a sick or injured animal. In this photo, FWC biologists and UF veterinary staff work together to obtain the weight of this manatee, Shamrock. Credits: Brittany Hall-Scharf, UF/IFAS

One of the medications used to treat red-tide-affected manatees once they are in a critical care facility is atropine, a medication used to treat certain types of nervous system poisonings. Atropine is administered to manatees either by an intravenous or subcutaneous route via an injection. The manatees are then kept in rehabilitation facilities until the toxins have cleared from their bodies and they can swim on their own.

In 2018, one of the four critical care facilities, ZooTampa, was out of service due to filtration system upgrades, which limited the number of manatees the state could take in. 
The compounding threats of algae blooms and lack of hospital space led to a triage situation in 2018. FWC officials say manatees sometimes had to be released before they were fully recovered to make room in the care facilities for other distressed animals.

Through a grant from the National Oceanic and Atmospheric Administration's ECOHAB program, Florida International University and Mote Marine Laboratory have launched a three-year project to improve veterinary care for rescued manatees by studying how the cells in their immune systems respond to certain antioxidants. The goal of the new research is to identify those antioxidants that may work better than the current treatment and accelerate the healing process.

\section{What can you do?}

1. Report any dead, sick, injured, or distressed manatees to the FWC Wildlife Hotline: 1-888-404-3922. Manatee behavior can alert researchers to environmental changes that may otherwise go unnoticed.

Scientists currently have no ways to prevent red tide itself because Karenia brevis is a naturally occurring organism. The goal is not to eliminate Karenia brevis but to minimize its food supply by reducing human-caused nutrient runoff into coastal waterways.

FWC and other organizations are conducting research and rescuing and rehabilitating manatees exposed to red tide.

According to FWC, 26 percent of the manatee carcasses recovered along Florida's Gulf Coast from January 1, 2018, to October 19, 2018, died due to exposure to Karenia brevis. Researchers at the FWC Fish and Wildlife Research Institute (FWRI) collaborate with citizen scientists, the University of South Florida, and Mote Marine Laboratory to monitor and track red tide. Biologists at FWRI work with other members of the Manatee Rescue and Rehabilitation Partnership (www.manateerescue.org) to rescue, rehabilitate, and release Florida manatees affected by red tides back into the wild.

2. Purchase the manatee license specialty plate for your vehicle or vessel's trailer from your local Florida Department of Highway Safety and Motor Vehicles office (https://www.flhsmv.gov/specialtytags/slp.html). The funds collected from these specialty plates go towards the research and conservation of these beloved manatees (http://myfwc.com/research/manatee/trust-fund/ license-plate/new-look/).
Treating a sick or injured manatee doesn't come cheap. It is estimated that it could cost upwards of $\$ 30,000$ to rehab one manatee over the course of the year. The facilities are only reimbursed about 40 percent from the state on average for the costs, sometimes much less.

3. Visit the citizen scientist Beach Conditions Reporting System (https://visitbeaches.org/) and participate in the data collection by reporting local beach conditions to their hotline (1-941-232-2437).

This collaboration between the University of South Florida and Mote Marine Laboratory assists FWC by providing information to the public regarding respiratory irritation and fish kills associated with red tide blooms.

\section{Become a citizen scientist and assist FWRI with water sampling.}

FWRI relies on local governments, organizations, and volunteers to collect water samples on a weekly, bi-monthly, or monthly basis. These water samples are evaluated for the presence of algae that cause harmful algal blooms (Figure 6), such as Karenia brevis. These data are used to inform communities throughout the state of Florida about the presence and intensity of red tide blooms. To sign up, visit: http://myfwc.com/research/redtide/monitoring/current/ offshore-monitoring/

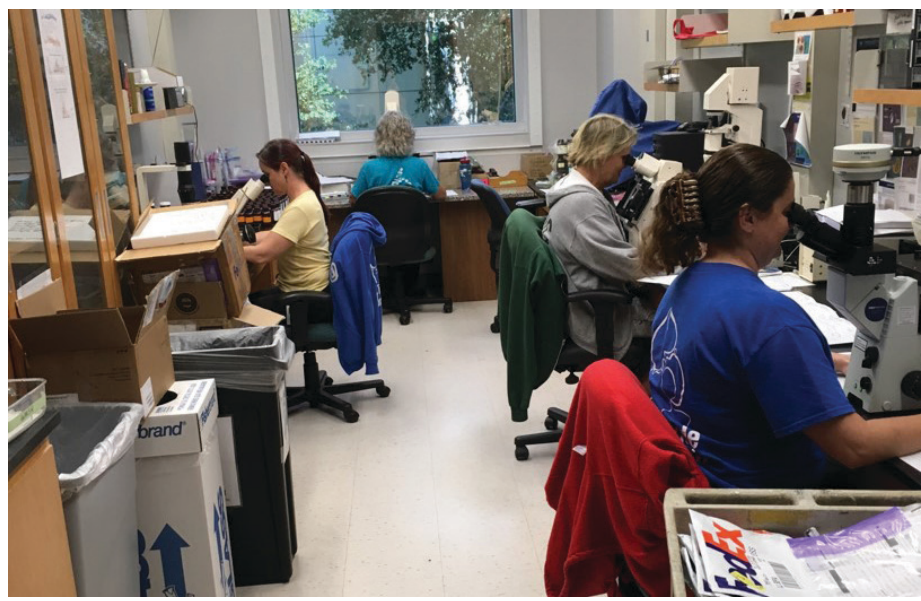

Figure 6. After water samples are collected and shipped to FWRI, biologists usemicroscopes to scan each sample for the presence of harmful algae such as red tide.

Credits: Florida Fish and Wildlife Conservation Commission

5. Help reduce nitrogen and phosphorus input to nearshore waters that intensify algal blooms. Here are some steps you can take:

- If you plan to use fertilizer at your residence, apply the proper amount at the right time of the year and with the right method. In Florida, summer rains wash fertilizers 
and other pollutants from yards into our rivers and bays. More than half of Florida counties ban the use of fertilizers during summer months to prevent excess nutrients from entering coastal waterways.

- Plant native trees and plants in your yard and create a planted native buffer around waterways. Plants can help reduce nutrient runoff by absorbing or filtering out nutrients before they can reach a water body.

- Be an informed voter. Laws and regulations to protect our waters from nutrient pollution are changing constantly, and as responsible citizens we need to support laws and regulations that better safeguard our waters and their inhabitants.

- Pick up after your pet to keep animal waste out of streams and bays.

- Don't blow lawn and yard clippings into the street. They wash down storm drains and into coastal waterbodies, introducing more nutrients.

\section{Conclusion}

Because manatees play a role in maintaining healthy ecosystems and are important to Florida's culture and economy, it is essential to be aware of human activities that put them at risk and reduce their chances of survival. Red tide occurs naturally in Florida's coastal waters, but in high concentrations it will sicken and kill manatees. Your actions to reduce inputs of nutrients that contribute to harmful algal blooms will improve the outlook for manatees, helping conserve Florida's state marine mammal for generations to come.

\section{References}

Brand, L. E., A. Compton. 2007. "Long-term increase in Karenia brevis abundance along the Southwest Florida Coast." Harmful Algae 6: 232-252

Capper, A., L. J. Flewelling, and K. Arthur. 2013. “Dietary Exposure to Harmful Algal Bloom (HAB) toxins in the Endangered Manatee (Trichechus manatus latirostris) and Green Sea Turtle (Chelonis mydas) in Florida, USA." Harmful Algae 28:1-9.

Flewelling, L. J. 2008. Vectors of Brevetoxins to Marine Mammals. Graduate Theses and Dissertations

Hoagland, P., D. M. Anderson, Y. Kaoru, and A. W. White. 2002. "The Economic Effects of Harmful Algal Blooms in the United States: Estimates, Assessment Issues, and Information Needs." Estuaries 25(4b):819-837.
Kirkpatrick, B., L. E. Fleming, D. Squicciarini, L. C. Backer, R. Clark, W. Abraham, J. Benson, Y. S. Cheng, D. Johnson, R. Pierce, J. Zaias, G. D. Bossart, and D. G. Baden. 2004. "Literature Review of Florida Red Tide: Implications for Human Heath Effects." Harmful Algae 3(2): 99-115.

Landsberg, J. H., L. J. Flewelling, and J. Naar. 2009. “Karenia brevis Red Tides, Brevetoxins in the Food Web, and Impacts on Natural Resources: Decadal Advancements." Harmful Algae 8:598-607.

Morgan, K. L., S. L. Larkin, and C. M. Adams. 2007. Public Costs of Florida Red Tides, 2007. Gainesville: University of Florida Institute of Food and Agricultural Sciences.

Solomon, B. D., C. M. Corey-Luse, and K. E. Halvorsen. 2004. "The Florida Manatee and Eco-Tourism: Toward a Safe Minimum Standard.” Ecological Economics 50:101-115.

National Oceanic and Atmospheric Administration. 2011. “Endangered Ocean: Manatees." Retrieved October 23, 2018, from

VISIT FLORIDA. 2017. 2016-2017 Year in Review. VISIT FLORIDA, Tallahassee, Fl. 